\title{
Kinetics and Mechanism of Anilinolyses of Aryl Methyl and Aryl Propyl Chlorothiophosphates in Acetonitrile ${ }^{\dagger}$
}

\author{
Hasi Rani Barai and Hai Whang Lee* \\ Department of Chemistry, Inha University, Incheon 402-751, Korea. *E-mail: hwlee@inha.ac.kr \\ Received May 21, 2014, Accepted May 30, 2014
}

\begin{abstract}
Nucleophilic substitution reactions of Y-aryl methyl (8) and Y-aryl propyl (10) chlorothiophosphates with substituted anilines and deuterated anilines are investigated kinetically in acetonitrile at $55.0^{\circ} \mathrm{C}$. A concerted mechanism is proposed for $\mathbf{8}$ based on the negative $\rho_{\mathrm{XY}}(=-0.23)$ value, while a stepwise mechanism with a rate-limiting leaving group departure from the intermediate is proposed for $\mathbf{1 0}$ based on the positive $\rho_{\mathrm{XY}}$ $(=+0.68)$ value. The deuterium kinetic isotope effects (DKIEs; $\left.k_{\mathrm{H}} / k_{\mathrm{D}}\right)$ are $0.89-1.28$ and $0.62-1.20$ with 8 and 10, respectively. Primary normal and secondary inverse DKIEs are rationalized by a frontside attack involving hydrogen bonded, four-center-type transition state and backside attack involving in-line-type transition state, respectively.
\end{abstract}

Key Words : Thiophosphoryl transfer reaction, Anilinolysis, Y-Aryl methyl and Y-aryl propyl chlorothiophosphates, Deuterium kinetic isotope effect, Cross-interaction constant

\section{Introduction}

As final part on going kinetic studies on the anilinolyses of the chlorothiophophates $\left[\left(\mathrm{R}_{1} \mathrm{O}\right)\left(\mathrm{R}_{2} \mathrm{O}\right) \mathrm{P}(=\mathrm{S}) \mathrm{Cl}\right.$-type where $\mathrm{R}_{1}$ $=\mathrm{R}_{2}=$ alkyl and/or aryl], the reactions of Y-aryl methyl $(\mathbf{8})$ and Y-aryl propyl (10) chlorothiophosphates with substituted anilines $\left(\mathrm{XC}_{6} \mathrm{H}_{4} \mathrm{NH}_{2}\right)$ and deuterated anilines $\left(\mathrm{XC}_{6} \mathrm{H}_{4} \mathrm{ND}_{2}\right)$ have been kinetically investigated in acetonitrile $(\mathrm{MeCN})$ at $55.0 \pm 0.1{ }^{\circ} \mathrm{C}$ (Scheme 1). The aim of this work is to obtain further information on the thiophosphoryl transfer reactions by comparing the anilinolyses of the following chlorothiophosphates in terms of the selectivity parameters, steric effects of the two ligands on the rate, reaction mechanism, deuterium kinetic isotope effects (DKIEs) and activation parameters: dimethyl $\left[\mathbf{1}:(\mathrm{MeO})_{2} \mathrm{P}(=\mathrm{S}) \mathrm{Cl}\right]$, ${ }^{\text {a }}$ ethyl methyl [2: $(\mathrm{MeO})(\mathrm{EtO}) \mathrm{P}(=\mathrm{S}) \mathrm{Cl}],{ }^{1 \mathrm{~b}}$ diethyl [3: $(\mathrm{EtO})_{2}$ $\mathrm{P}(=\mathrm{S}) \mathrm{Cl}],{ }^{1 \mathrm{a}}$ ethyl propyl [4: $\left.(\mathrm{EtO})(\mathrm{PrO}) \mathrm{P}(=\mathrm{S}) \mathrm{Cl}\right],{ }^{1 \mathrm{~b}}$ dipropyl [5: $\left.(\mathrm{PrO})_{2} \mathrm{P}(=\mathrm{S}) \mathrm{Cl}\right],{ }^{1 \mathrm{c}}$ dibutyl $\left[6:(\mathrm{BuO})_{2} \mathrm{P}(=\mathrm{S}) \mathrm{Cl}\right],{ }^{1 \mathrm{~d}}$ diisopropyl (7: $\left.(i \text {-PrO })_{2} \mathrm{P}(=\mathrm{S}) \mathrm{Cl}\right],{ }^{1 \mathrm{~b}} \mathrm{Y}$-aryl ethyl [9: $(\mathrm{EtO})\left(\mathrm{YC}_{6} \mathrm{H}_{4} \mathrm{O}\right)-$ $\mathrm{P}(=\mathrm{S}) \mathrm{Cl}]{ }^{1 \mathrm{e}} \mathrm{Y}$-aryl phenyl $\left[11:(\mathrm{PhO})\left(\mathrm{YC}_{6} \mathrm{H}_{4} \mathrm{O}\right) \mathrm{P}(=\mathrm{S}) \mathrm{Cl}\right]^{1 \mathrm{f}}$

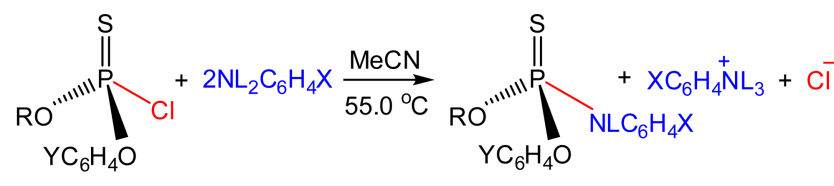

$\mathrm{R}=\mathrm{Me}(\mathbf{8}), \operatorname{Pr}(\mathbf{1 0}) ; \mathrm{L}=\mathrm{H}, \mathrm{D}$

$\mathrm{X}=4-\mathrm{MeO}, 4-\mathrm{Me}, 3-\mathrm{Me}, \mathrm{H}, 4-\mathrm{Cl}, 3-\mathrm{Cl} ; \mathrm{Y}=4-\mathrm{MeO}, 4-\mathrm{Me}, \mathrm{H}, 3-\mathrm{MeO}, 4-\mathrm{Cl}$

Scheme 1. Reactions of Y-aryl methyl (8) and Y-aryl propyl (10) chlorothiophosphates with $\mathrm{XC}_{6} \mathrm{H}_{4} \mathrm{NH}_{2}\left(\mathrm{D}_{2}\right)$ in $\mathrm{MeCN}$ at $55.0{ }^{\circ} \mathrm{C}$.

${ }^{\dagger}$ Last publication of (thio)phosphoryl transfer reaction series studied in this lab since 1999. Lee, H. W. thanks all the coworkers, especially Bangladeshi Crew for their endless work: Guha, A. K.; Adhikary, K. K.; Dey, S; Hoque, M. E. U.; Dey, N. K.; Lumbiny, B. J.; and finally Barai, H. R. and Y-aryl 4-chlorophenyl [12: $\left(4-\mathrm{Cl}-\mathrm{C}_{6} \mathrm{H}_{4} \mathrm{O}\right)\left(\mathrm{YC}_{6} \mathrm{H}_{4} \mathrm{O}\right)$ $\mathrm{P}(=\mathrm{S}) \mathrm{Cl}]^{1 \mathrm{f}}$ chlorothiophosphates. 1-12 are numbered according to the sequence of the summation of the Taft steric constants of the two ligands $\left(\mathrm{R}_{1} \text { and } \mathrm{R}_{2}\right)^{2,3}$

\section{Results and Discussion}

Tables 1-3 list the second-order rate constants $\left(k_{\mathrm{H}} / \mathrm{M}^{-1} \mathrm{~s}^{-1}\right)$, $\rho_{\mathrm{X}(\mathrm{H})}$ and $\beta_{\mathrm{X}(\mathrm{H})}$ with $\mathrm{X}$, and $\rho_{\mathrm{Y}(\mathrm{H})}$ with $\mathrm{Y}$, respectively, of the reactions of $\mathbf{8}$ and $\mathbf{1 0}$ with $\mathrm{X}$-anilines. The substituent effects of $\mathrm{X}$ and $\mathrm{Y}$ on the reaction rates are compatible with a typical nucleophilic substitution reaction and the rate increases with more basic aniline and with more electronwithdrawing substituent Y. The rates of $\mathbf{8}$ are 2-7 times faster than those of $\mathbf{1 0}$ depending on $\mathrm{X}$ and/or Y. The free energy relationships with $\mathrm{X}$ and $\mathrm{Y}$ are all linear. The Hammett (Figs. S1 and S2 with $\mathbf{8}$ and 10, respectively) and Brönsted (Figs. S3 and S4 with $\mathbf{8}$ and 10, respectively) plots for substituent $\mathrm{X}$ variations in the nucleophiles, and Hammett plots (Figs. S5 and S6 with $\mathbf{8}$ and 10, respectively) for substituent $\mathrm{Y}$ variations in the substrates are shown in the supporting information. The magnitudes of the $\rho_{\mathrm{X}(\mathrm{H})}(=-2.60$ to -2.51$)$ and $\beta_{\mathrm{X}(\mathrm{H})}(=0.89-0.93)$ values with 8 are somewhat smaller than those $\left(\rho_{\mathrm{X}(\mathrm{H})}=-3.30\right.$ to -2.97 and $\beta_{\mathrm{X}(\mathrm{H})}=1.05-$ $1.17)$ with 10. The $\rho_{\mathrm{Y}(\mathrm{H})}(=0.60-0.78)$ values with 8 are more or less smaller than those $\left(\rho_{\mathrm{Y}(\mathrm{H})}=0.62-1.04\right)$ with 10. This may suggest that the degrees of both bond formation and cleavage with $\mathbf{1 0}$ are greater than those with $\mathbf{8}$ in the transition state (TS). The $\rho_{\mathrm{X}(\mathrm{H})}$ values invariably decrease (i.e., more negative value; $\partial \rho_{\mathrm{X}(\mathrm{H})}<0$ ) with $\mathbf{8}$, whereas those invariably increase (i.e., less negative value; $\left.\partial \rho_{\mathrm{X}(\mathrm{H})}>0\right)$ with 10 as substituent $Y$ becomes more electron-withdrawing $\left(\partial \sigma_{\mathrm{Y}}>0\right)$. Meanwhile, the $\rho_{\mathrm{Y}(\mathrm{H})}$ values consistently decrease (i.e., less positive value; $\partial \rho_{\mathrm{Y}(\mathrm{H})}<0$ ) with $\mathbf{8}$, whereas those consistently increase with $\mathbf{1 0}$ (i.e., more positive value; 
$\left.\partial \rho_{\mathrm{Y}(\mathrm{H})}>0\right)$ as the pyridine becomes less basic $\left(\partial \sigma_{\mathrm{X}}>0\right)$. Note that the variation trends of the $\rho_{\mathrm{X}(\mathrm{H})}$ values for substituent $\mathrm{X}$ variations in the nucleophiles and $\rho_{\mathrm{Y}(\mathrm{H})}$ values for substituent $\mathrm{Y}$ variations in the substrates with $\mathbf{8}$ is opposite to those with 10, resulting in $\partial \rho_{\mathrm{X}(\mathrm{H})} / \partial \sigma_{\mathrm{Y}}=(-) /(+)<0$ and $\partial \rho_{\mathrm{Y}(\mathrm{H})} / \partial \sigma_{\mathrm{X}}=(-) /$ $(+)<0$ with 8 , while $\partial \rho_{\mathrm{X}(\mathrm{H})} / \partial \sigma_{\mathrm{Y}}=(+) /(+)>0$ and $\partial \rho_{\mathrm{Y}(\mathrm{H})} / \partial \sigma_{\mathrm{X}}$
$=(+) /(+)>0$ with $\mathbf{1 0}$ (vide infra).

Table 4 summarizes the second-order rate constants $\left(k_{\mathrm{H}}\right)$ with unsubstituted aniline, natural bond order (NBO) charges at the reaction center $\mathrm{P}$ atom in the gas phase $[\mathrm{B} 3 \mathrm{LYP} / 6-$ $311+\mathrm{G}(\mathrm{d}, \mathrm{p})$ level of theory], summations of the Taft steric constants of $\mathrm{R}_{1}$ and $\mathrm{R}_{2}\left[\Sigma E_{\mathrm{S}}=E_{\mathrm{S}}\left(\mathrm{R}_{1}\right)+E_{\mathrm{S}}\left(\mathrm{R}_{2}\right)\right]$, ${ }^{2,3}$ Brönsted

Table 1. Second-Order Rate Constants $\left(k_{\mathrm{H}} \times 10^{4} / \mathrm{M}^{-1} \mathrm{~s}^{-1}\right)$ of the Reactions of $\mathbf{8}$ and $\mathbf{1 0}$ with $\mathrm{XC}_{6} \mathrm{H}_{4} \mathrm{NH}_{2}$ in $\mathrm{MeCN}$ at $55.0{ }^{\circ} \mathrm{C}$

\begin{tabular}{ccccccc}
\hline substrate & $\mathrm{X} \backslash \mathrm{Y}$ & $4-\mathrm{MeO}$ & $4-\mathrm{Me}$ & $\mathrm{H}$ & $3-\mathrm{MeO}$ & $4-\mathrm{Cl}$ \\
\hline $\mathbf{8}$ & $4-\mathrm{MeO}$ & $42.5 \pm 0.2$ & $49.0 \pm 0.1$ & $60.7 \pm 0.3$ & $80.8 \pm 0.3$ & $105 \pm 1$ \\
& $4-\mathrm{Me}$ & $17.1 \pm 0.1$ & $19.0 \pm 0.1$ & $25.8 \pm 0.2$ & $30.9 \pm 0.3$ & $39.3 \pm 0.2$ \\
& $3-\mathrm{Me}$ & $7.83 \pm 0.03$ & $8.64 \pm 0.1$ & $10.2 \pm 0.1$ & $13.2 \pm 0.1$ & $16.5 \pm 0.2$ \\
& $\mathrm{H}$ & $5.32 \pm 0.03$ & $6.45 \pm 0.04$ & $7.85 \pm 0.01$ & $8.49 \pm 0.01$ & $12.1 \pm 0.1$ \\
& $4-\mathrm{Cl}$ & $1.74 \pm 0.02$ & $1.97 \pm 0.01$ & $2.37 \pm 0.02$ & $2.89 \pm 0.01$ & $3.79 \pm 0.01$ \\
& $3-\mathrm{Cl}$ & $0.914 \pm 0.001$ & $1.04 \pm 0.01$ & $1.23 \pm 0.01$ & $1.45 \pm 0.01$ & $1.90 \pm 0.03$ \\
$\mathbf{1 0}$ & $4-\mathrm{MeO}$ & $19.2 \pm 0.1$ & $22.3 \pm 0.2$ & $25.4 \pm 0.2$ & $30.2 \pm 0.1$ & $41.7 \pm 0.1$ \\
& $4-\mathrm{Me}$ & $6.44 \pm 0.02$ & $7.40 \pm 0.2$ & $7.97 \pm 0.01$ & $9.75 \pm 0.01$ & $15.4 \pm 0.2$ \\
& $3-\mathrm{Me}$ & $2.15 \pm 0.01$ & $2.59 \pm 0.02$ & $3.05 \pm 0.02$ & $3.77 \pm 0.01$ & $5.69 \pm 0.01$ \\
& $\mathrm{H}$ & $1.55 \pm 0.01$ & $1.81 \pm 0.01$ & $2.04 \pm 0.01$ & $2.63 \pm 0.01$ & $4.09 \pm 0.01$ \\
& $4-\mathrm{Cl}$ & $0.320 \pm 0.003$ & $0.402 \pm 0.001$ & $0.495 \pm 0.001$ & $0.717 \pm 0.001$ & $1.02 \pm 0.01$ \\
& $3-\mathrm{Cl}$ & $0.126 \pm 0.001$ & $0.163 \pm 0.001$ & $0.205 \pm 0.001$ & $0.284 \pm 0.001$ & $0.454 \pm 0.001$ \\
\hline
\end{tabular}

Table 2. Hammett $\left(\rho_{\mathrm{X}(\mathrm{H})}\right)$ and Brönsted $\left(\beta_{\mathrm{X}(\mathrm{H})}\right)$ Coefficients ${ }^{a}$ with $\mathrm{X}$ of the Reactions of $\mathbf{8}$ and $\mathbf{1 0}$ with $\mathrm{XC}_{6} \mathrm{H}_{4} \mathrm{NH}_{2}$ in $\mathrm{MeCN}$ at $55.0{ }^{\circ} \mathrm{C}$

\begin{tabular}{ccccccc}
\hline substrate & $\mathrm{Y}$ & $4-\mathrm{MeO}$ & $4-\mathrm{Me}$ & $\mathrm{H}$ & $3-\mathrm{MeO}$ & $4-\mathrm{Cl}$ \\
\hline $\mathbf{8}$ & $-\rho_{\mathrm{X}(\mathrm{H})}$ & $2.51 \pm 0.10$ & $2.51 \pm 0.10$ & $2.56 \pm 0.11$ & $2.62 \pm 0.12$ & $2.60 \pm 0.12$ \\
& $\beta_{\mathrm{X}(\mathrm{H})}$ & $0.89 \pm 0.11$ & $0.89 \pm 0.10$ & $0.91 \pm 0.10$ & $0.93 \pm 0.12$ & $0.93 \pm 0.12$ \\
\multirow{2}{*}{$\mathbf{1 0}$} & $-\rho_{\mathrm{X}(\mathrm{H})}$ & $3.30 \pm 0.11$ & $3.22 \pm 0.12$ & $3.13 \pm 0.12$ & $3.00 \pm 0.12$ & $2.97 \pm 0.11$ \\
& $\beta_{\mathrm{X}(\mathrm{H})}$ & $1.17 \pm 0.11$ & $1.14 \pm 0.11$ & $1.11 \pm 0.12$ & $1.07 \pm 0.12$ & $1.05 \pm 0.11$ \\
\hline
\end{tabular}

${ }^{a}$ Correlation coefficients (r) of the $\rho_{\mathrm{X}(\mathrm{H})}$ and $\beta_{\mathrm{X}(\mathrm{H})}$ values are better than 0.986 .

Table 3. Hammett Coefficients $\left(\rho_{\mathrm{Y}(\mathrm{H})}\right)^{a}$ with $\mathrm{Y}$ of the Reactions of $\mathbf{8}$ and $\mathbf{1 0}$ with $\mathrm{XC}_{6} \mathrm{H}_{4} \mathrm{NH}_{2}$ in $\mathrm{MeCN}$ at $55.0{ }^{\circ} \mathrm{C}$

\begin{tabular}{ccccccc}
\hline substrate $\mathrm{X}$ & $4-\mathrm{MeO}$ & $4-\mathrm{Me}$ & $3-\mathrm{Me}$ & $\mathrm{H}$ & 4-Cl & $3-\mathrm{Cl}$ \\
\hline $\mathbf{8}$ & $0.78 \pm 0.03$ & $0.74 \pm 0.01$ & $0.64 \pm 0.03$ & $0.64 \pm 0.04$ & $0.64 \pm 0.03$ & $0.60 \pm 0.03$ \\
$\mathbf{1 0}$ & $0.62 \pm 0.04$ & $0.66 \pm 0.07$ & $0.77 \pm 0.05$ & $0.77 \pm 0.06$ & $0.96 \pm 0.04$ & $1.04 \pm 0.05$
\end{tabular}

${ }^{a}$ Correlation coefficients (r) of $\rho_{\mathrm{Y}(\mathrm{H})}$ values are better than 0.983 .

Table 4. Summary of the Second-Order Rate Constants $\left(k_{\mathrm{H}} \times 10^{4} / \mathrm{M}^{-1} \mathrm{~s}^{-1}\right)$ with $\mathrm{C}_{6} \mathrm{H}_{5} \mathrm{NH}_{2}, \mathrm{NBO}$ Charges at the Reaction Center P Atom, $\Sigma E_{\mathrm{S}}$ $=E_{\mathrm{S}}\left(\mathrm{R}_{1}\right)+E_{\mathrm{S}}\left(\mathrm{R}_{2}\right), \beta_{\mathrm{X}(\mathrm{H})}, \rho_{\mathrm{XY}(\mathrm{H})}, k_{\mathrm{H}} / k_{\mathrm{D}}$ and Variation Trends of $k_{\mathrm{H}} / k_{\mathrm{D}}$ with $\mathrm{X}$ and $\mathrm{Y}$ for the Reactions of 1-12 with $\mathrm{XC}_{6} \mathrm{H}_{4} \mathrm{NH}_{2}\left(\mathrm{D}_{2}\right)$ in $\mathrm{MeCN}$ at $55.0^{\circ} \mathrm{C}$

\begin{tabular}{|c|c|c|c|c|c|c|c|}
\hline substrate & $10^{4} k_{\mathrm{H}}$ & charge at $\mathrm{P}$ & $-\Sigma E_{\mathrm{S}}$ & $\beta_{\mathrm{X}(\mathrm{H})}$ & $\rho_{\mathrm{XY}(\mathrm{H})}$ & $k_{\mathrm{H}} / k_{\mathrm{D}}$ & trend \\
\hline 1: $(\mathrm{MeO})_{2} \mathrm{P}(=\mathrm{S}) \mathrm{Cl}$ & 10.9 & 1.687 & 0.00 & 0.99 & - & $0.95-1.06$ & $\uparrow$ \\
\hline 2: $(\mathrm{MeO})(\mathrm{EtO}) \mathrm{P}(=\mathrm{S}) \mathrm{Cl}$ & 8.44 & 1.693 & 0.07 & 0.79 & - & $0.66-0.99$ & $\uparrow$ \\
\hline 4: $(\mathrm{EtO})(\mathrm{PrO}) \mathrm{P}(=\mathrm{S}) \mathrm{Cl}$ & 3.89 & 1.700 & 0.43 & 0.93 & - & $0.78-1.19$ & $\downarrow$ \\
\hline 5: $(\mathrm{PrO})_{2} \mathrm{P}(=\mathrm{S}) \mathrm{Cl}$ & 3.00 & 1.702 & 0.72 & 1.14 & - & $1.11-1.35$ & $\downarrow$ \\
\hline 6: $(\mathrm{BuO})_{2} \mathrm{P}(=\mathrm{S}) \mathrm{Cl}$ & 3.22 & 1.703 & 0.78 & 1.17 & - & $1.10-1.35$ & $\downarrow$ \\
\hline 7: $(i-\mathrm{PrO})_{2} \mathrm{P}(=\mathrm{S}) \mathrm{Cl}$ & 2.02 & 1.723 & 0.94 & 0.87 & - & $1.06-1.21$ & $\downarrow$ \\
\hline 8: $(\mathrm{MeO})\left(\mathrm{YC}_{6} \mathrm{H}_{4} \mathrm{O}\right) \mathrm{P}(=\mathrm{S}) \mathrm{Cl}$ & $7.85^{a}$ & $1.686^{a}$ & $2.48^{a}$ & $0.89-0.93$ & -0.23 & $0.89-1.28$ & $\downarrow \rightarrow$ \\
\hline 9: $(\mathrm{EtO})\left(\mathrm{YC}_{6} \mathrm{H}_{4} \mathrm{O}\right) \mathrm{P}(=\mathrm{S}) \mathrm{Cl}$ & $2.80^{a}$ & $1.687^{a}$ & $2.55^{a}$ & $1.10-1.19$ & -0.28 & $1.06-1.27$ & $\downarrow \rightarrow$ \\
\hline 10: $(\mathrm{PrO})\left(\mathrm{YC}_{6} \mathrm{H}_{4} \mathrm{O}\right) \mathrm{P}(=\mathrm{S}) \mathrm{Cl}$ & $2.04^{a}$ & $1.687^{a}$ & $2.84^{a}$ & $1.05-1.17$ & +0.68 & $0.62-1.20$ & $\uparrow \rightarrow$ \\
\hline 11: $(\mathrm{PhO})\left(\mathrm{YC}_{6} \mathrm{H}_{4} \mathrm{O}\right) \mathrm{P}(=\mathrm{S}) \mathrm{Cl}$ & $1.01^{a}$ & $1.661^{a}$ & $4.96^{a}$ & $1.34-1.41$ & -0.22 & $1.11-1.33$ & $\downarrow \rightarrow$ \\
\hline 12: $\left(4-\mathrm{Cl}-\mathrm{C}_{6} \mathrm{H}_{4} \mathrm{O}\right)\left(\mathrm{YC}_{6} \mathrm{H}_{4} \mathrm{O}\right) \mathrm{P}(=\mathrm{S}) \mathrm{Cl}$ & $1.48^{a}$ & $1.667^{a}$ & $>4.96^{a}$ & $1.23-1.48$ & -0.50 & $1.10-1.46$ & $\downarrow \rightarrow$ \\
\hline
\end{tabular}




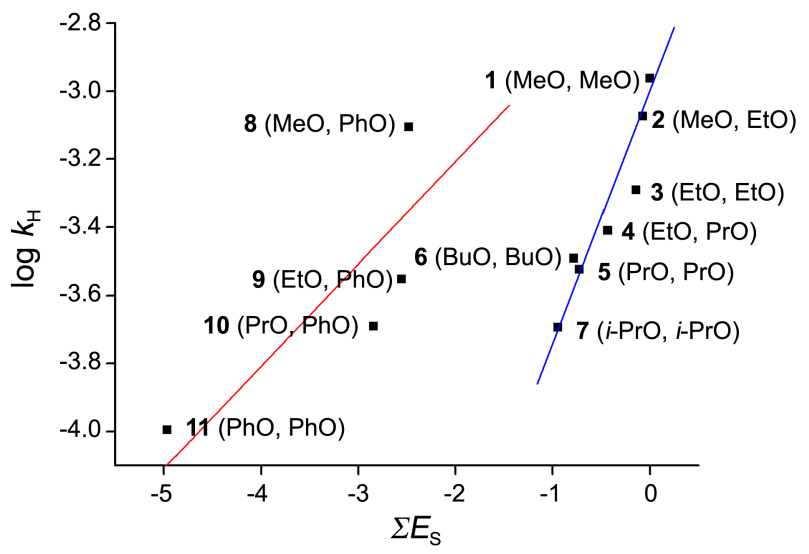

Figure 1. Taft plot of $\log k_{\mathrm{H}} v s \Sigma E_{\mathrm{S}}$ for the reactions of 1-11 with $\mathrm{C}_{6} \mathrm{H}_{5} \mathrm{NH}_{2}$ in $\mathrm{MeCN}$ at $55.0{ }^{\circ} \mathrm{C}$. The number of the substrate and two ligands of $\mathrm{R}_{1} \mathrm{O}$ and $\mathrm{R}_{2} \mathrm{O}$ are displayed next to the corresponding point.

coefficients $\left(\beta_{\mathrm{X}(\mathrm{H})}\right)$, cross-interaction constants $\left(\mathrm{CICs} ; \rho_{\mathrm{XY}(\mathrm{H})}\right){ }^{4}$ DKIEs $\left(k_{\mathrm{H}} / k_{\mathrm{D}}\right)$ and variation trends of the $k_{\mathrm{H}} / k_{\mathrm{D}}$ values with $\mathrm{X}$ in the nucleophiles and with $\mathrm{Y}$ in the substrates for the reactions of 1-12 with $\mathrm{XC}_{6} \mathrm{H}_{4} \mathrm{NH}_{2}\left(\mathrm{D}_{2}\right)$ in $\mathrm{MeCN}$ at $55.0{ }^{\circ} \mathrm{C}$. The variation trends of the $k_{\mathrm{H}} / k_{\mathrm{D}}$ values with $\mathrm{X}$ and $\mathrm{Y}$ are represented by an vertical and horizontal arrows, respectively. The vertical ( $\uparrow$ or $\downarrow$ ) and horizontal arrows ( $\rightarrow$ or $\longleftarrow$ ) indicate the direction of the consistent increase in the $k_{\mathrm{H}} / k_{\mathrm{D}}$ value with $\mathrm{X}$ and $\mathrm{Y}$, respectively. For example, $\uparrow$ indicates an increase of the $k_{\mathrm{H}} / k_{\mathrm{D}}$ value with a more electron-donating $\mathrm{X}$, and $\rightarrow$ indicates an increase of the $k_{\mathrm{H}} / k_{\mathrm{D}}$ value with a more electron-withdrawing Y.

The sequence of the anilinolysis rates of 1-11 is not consistent with expectations for the positive NBO charge at the reaction center $\mathrm{P}$ atom, indicating that the inductive effects of the two ligands are not major factor to decide the anilinolysis rates of the chlorothiophosphates. According to Taft Eq. of ' $\log k_{\mathrm{H}}=\delta \Sigma E_{\mathrm{S}}+\mathrm{C}$ ', Figure 1 shows the Taft plot of $\log k_{\mathrm{H}}$ (with $\mathrm{C}_{6} \mathrm{H}_{5} \mathrm{NH}_{2}$ ) against the summation of the Taft steric constants of the two ligands for the anilinolyses of 111 in $\mathrm{MeCN}$ at $55.0^{\circ} \mathrm{C}$, giving the sensitivity coefficients of $\delta=0.65 \pm 0.09(\mathrm{r}=0.948)$ and $\delta=0.25 \pm 0.27(\mathrm{r}=0.803)$ with seven substrates of 1-7 ( $a$ group containing two alkoxy ligands) and four substrates of 8-11 $[b$ group containing phenoxy ligand(s)], respectively. ${ }^{5}$ It is worthy of note that: (i) the sequence of the anilinolysis rates is inversely proportional (roughly) to the size of the two ligands; (ii) but divided into two groups; $a$ group of 1-7 and $b$ group of 8-11; and (iii) the correlation coefficient with $b$ group is not good. The steric effects of the two ligands on the anilinolysis rates of the $\mathrm{P}=\mathrm{O}$ counterparts, chlorophosphates $\left[\left(\mathrm{R}_{1} \mathrm{O}\right)\left(\mathrm{R}_{2} \mathrm{O}\right)\right.$ $\mathrm{P}(=\mathrm{O}) \mathrm{Cl}$-type], show the same trends as those of the chlorothiophosphates. $^{1 \mathrm{a}, \mathrm{e}, 6}$ These indicate that the steric effects of the two ligands on the anilinolysis rates of chloro(thio)phosphates play an important role and that $a$ group is 'very different' from $b$ group regarding the steric effects of the two ligands on the rate. ${ }^{7}$

Figure 2 shows the $\rho_{\mathrm{XY}(\mathrm{H})}$ values for the reactions of $\mathbf{8}$ and 10 with $\mathrm{X}$-anilines in $\mathrm{MeCN}$ at $55.0{ }^{\circ} \mathrm{C}$, based on the defini-
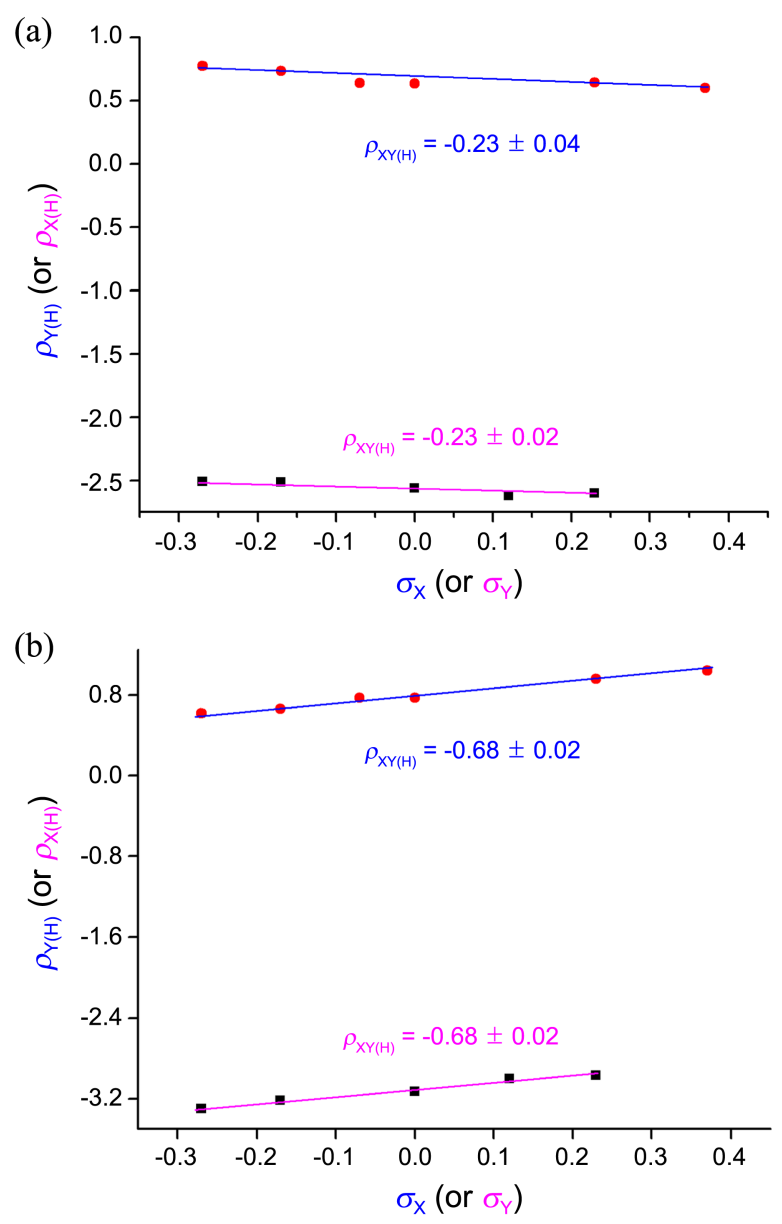

Figure 2. Plots of $\rho_{\mathrm{X}(\mathrm{H})} v s \sigma_{\mathrm{Y}}$ and $\rho_{\mathrm{Y}(\mathrm{H})} v s \sigma_{\mathrm{X}}$ of the reactions of $\mathbf{8}$ and 10 with $\mathrm{XC}_{6} \mathrm{H}_{4} \mathrm{NH}_{2}$ in $\mathrm{MeCN}$ at $55.0{ }^{\circ} \mathrm{C}$. The obtained $\rho_{\mathrm{XY}(\mathrm{H})}$ values by multiple regression are: (a) $\rho_{\mathrm{XY}(\mathrm{H})}=-0.23 \pm 0.10(\mathrm{r}=$ $0.976)$ with 8 ; (b) $\rho_{\mathrm{XY}(\mathrm{H})}=+0.68 \pm 0.11(\mathrm{r}=0.980)$ with $\mathbf{1 0}$.

tion of the CIC: $\log \left(k_{\mathrm{XY}} / k_{\mathrm{HH}}\right)=\rho_{\mathrm{X}} \sigma_{\mathrm{X}}+\rho_{\mathrm{Y}} \sigma_{\mathrm{Y}}+\rho_{\mathrm{XY}} \sigma_{\mathrm{X}} \sigma_{\mathrm{Y}}$ hence, $\rho_{\mathrm{XY}}=\partial^{2} \log \left(k_{\mathrm{XY}} / k_{\mathrm{HH}}\right) /\left(\partial \sigma_{\mathrm{X}} \partial \sigma_{\mathrm{Y}}\right)=\partial \rho_{\mathrm{X}} / \partial \sigma_{\mathrm{Y}}=\partial \rho_{\mathrm{Y}} /$ $\partial \sigma_{\mathrm{X}}{ }^{4}{ }^{4}$ The signs of the $\rho_{\mathrm{XY}(\mathrm{H})}$ are negative $\left(\rho_{\mathrm{XY}(\mathrm{H})}=-0.23\right)$ and positive $\left(\rho_{\mathrm{XY}(\mathrm{H})}=+0.68\right)$ for $\mathbf{8}$ and 10, respectively (vide supra). Thus, a concerted mechanism is proposed for $\mathbf{8}$ while a stepwise mechanism with a rate-limiting leaving group departure from the intermediate for 10, because the $\rho_{\mathrm{XY}}$ has a negative value in a concerted $\mathrm{S}_{\mathrm{N}} 2$ (or a stepwise mechanism with a rate-limiting bond formation) and a positive value for a stepwise mechanism with a rate-limiting leaving group expulsion from the intermediate. ${ }^{4}$ The degree of tightness of the TS structure with $\mathbf{1 0}$ is greater than that with 8 because the magnitude of $\rho_{\mathrm{XY}}$ is inversely proportional to the distance between $\mathrm{X}$ and $\mathrm{Y}$ through the reaction center. $^{4,8}$

Tables 5 and 6 list the second-order rate constants $\left(k_{\mathrm{D}} / \mathrm{M}^{-1}\right.$ $\left.\mathrm{s}^{-1}\right)$ with the deuterated anilines $\left(\mathrm{XC}_{6} \mathrm{H}_{4} \mathrm{ND}_{2}\right)$ and DKIEs $\left(k_{\mathrm{H}} / k_{\mathrm{D}}\right)$ with 8 and 10 in $\mathrm{MeCN}$ at $55.0{ }^{\circ} \mathrm{C}$, respectively. The DKIEs show primary normal $\left(k_{\mathrm{H}} / k_{\mathrm{D}}>1\right)$ and secondary inverse $\left(k_{\mathrm{H}} / k_{\mathrm{D}}<1\right)$ depending on the substituents $\mathrm{X}$ and/or Y for both $8\left(k_{\mathrm{H}} / k_{\mathrm{D}}=0.89-1.28\right)$ and $10\left(k_{\mathrm{H}} / k_{\mathrm{D}}=0.62-1.20\right)$. The variation trends of the $k_{\mathrm{H}} / k_{\mathrm{D}}$ values with $\mathrm{Y}$ are the same for both $\mathbf{8}$ and 10, and the $k_{\mathrm{H}} / k_{\mathrm{D}}$ values become larger with a 
Table 5. Second-Order Rate Constants $\left(k_{\mathrm{D}} \times 10^{4} / \mathrm{M}^{-1} \mathrm{~s}^{-1}\right)$ of the Reactions of $\mathbf{8}$ and $\mathbf{1 0}$ with $\mathrm{XC}_{6} \mathrm{H}_{4} \mathrm{ND}_{2}$ in $\mathrm{MeCN}$ at $55.0^{\circ} \mathrm{C}$

\begin{tabular}{ccccccc}
\hline substrate & $\mathrm{X} \backslash \mathrm{Y}$ & $4-\mathrm{MeO}$ & $4-\mathrm{Me}$ & $\mathrm{H}$ & $3-\mathrm{MeO}$ & $4-\mathrm{Cl}$ \\
\hline $\mathbf{8}$ & $4-\mathrm{Me}$ & $19.3 \pm 0.1$ & $20.5 \pm 0.1$ & $27.4 \pm 0.1$ & $32.8 \pm 0.2$ & $39.4 \pm 0.1$ \\
& $\mathrm{H}$ & $4.90 \pm 0.01$ & $5.75 \pm 0.01$ & $7.01 \pm 0.01$ & $7.14 \pm 0.01$ & $9.88 \pm 0.01$ \\
& $4-\mathrm{Cl}$ & $1.48 \pm 0.01$ & $1.63 \pm 0.01$ & $1.93 \pm 0.01$ & $2.34 \pm 0.01$ & $2.96 \pm 0.01$ \\
$\mathbf{1 0}$ & $4-\mathrm{MeO}$ & $21.6 \pm 0.1$ & $23.1 \pm 0.3$ & $25.3 \pm 0.1$ & $26.9 \pm 0.1$ & $34.8 \pm 0.1$ \\
& $4-\mathrm{Me}$ & $7.34 \pm 0.01$ & $7.93 \pm 0.01$ & $8.03 \pm 0.01$ & $8.95 \pm 0.01$ & $13.5 \pm 0.2$ \\
& $3-\mathrm{Me}$ & $2.55 \pm 0.02$ & $2.79 \pm 0.01$ & $3.08 \pm 0.01$ & $3.57 \pm 0.01$ & $5.18 \pm 0.01$ \\
& $\mathrm{H}$ & $1.86 \pm 0.01$ & $2.03 \pm 0.01$ & $2.06 \pm 0.01$ & $2.51 \pm 0.01$ & $3.04 \pm 0.01$ \\
& $4-\mathrm{Cl}$ & $0.422 \pm 0.001$ & $0.459 \pm 0.001$ & $0.504 \pm 0.001$ & $0.703 \pm 0.001$ & $0.971 \pm 0.001$ \\
& $3-\mathrm{Cl}$ & $0.203 \pm 0.001$ & $0.221 \pm 0.001$ & $0.250 \pm 0.001$ & $0.285 \pm 0.001$ & $0.440 \pm 0.001$ \\
\hline
\end{tabular}

Table 6. DKIEs $\left(k_{\mathrm{H}} / k_{\mathrm{D}}\right)$ of the Reactions of $\mathbf{8}$ and $\mathbf{1 0}$ with $\mathrm{XC}_{6} \mathrm{H}_{4} \mathrm{NH}_{2}\left(\mathrm{D}_{2}\right)$ in $\mathrm{MeCN}$ at $55.0{ }^{\circ} \mathrm{C}$

\begin{tabular}{ccccccc}
\hline substrate & $\mathrm{X} \backslash \mathrm{Y}$ & $4-\mathrm{MeO}$ & $4-\mathrm{Me}$ & $\mathrm{H}$ & $3-\mathrm{MeO}$ & $4-\mathrm{Cl}$ \\
\hline $\mathbf{8}$ & $4-\mathrm{Me}$ & $0.886 \pm 0.007$ & $0.927 \pm 0.007$ & $0.942 \pm 0.008$ & $0.973 \pm 0.011$ & $0.997 \pm 0.006$ \\
& $\mathrm{H}$ & $1.09 \pm 0.01$ & $1.12 \pm 0.01$ & $1.12 \pm 0.01$ & $1.19 \pm 0.01$ & $1.22 \pm 0.01$ \\
& $4-\mathrm{Cl}$ & $1.18 \pm 0.02$ & $1.21 \pm 0.01$ & $1.22 \pm 0.01$ & $1.24 \pm 0.01$ & $1.28 \pm 0.01$ \\
$\mathbf{1 0}$ & $4-\mathrm{MeO}$ & $0.889 \pm 0.006$ & $0.965 \pm 0.015$ & $1.00 \pm 0.01$ & $1.12 \pm 0.01$ & $1.20 \pm 0.01$ \\
& $4-\mathrm{Me}$ & $0.877 \pm 0.003$ & $0.933 \pm 0.003$ & $0.993 \pm 0.002$ & $1.09 \pm 0.01$ & $1.14 \pm 0.02$ \\
& $3-\mathrm{Me}$ & $0.843 \pm 0.008$ & $0.928 \pm 0.008$ & $0.990 \pm 0.007$ & $1.06 \pm 0.01$ & $1.10 \pm 0.01$ \\
& $\mathrm{H}$ & $0.833 \pm 0.007$ & $0.892 \pm 0.007$ & $0.990 \pm 0.007$ & $1.05 \pm 0.01$ & $1.07 \pm 0.01$ \\
& $4-\mathrm{Cl}$ & $0.758 \pm 0.007$ & $0.876 \pm 0.003$ & $0.982 \pm 0.003$ & $1.02 \pm 0.01$ & $1.05 \pm 0.01$ \\
& $3-\mathrm{Cl}$ & $0.621 \pm 0.006$ & $0.738 \pm 0.006$ & $0.820 \pm 0.005$ & $0.997 \pm 0.005$ & $1.03 \pm 0.01$ \\
\hline
\end{tabular}

${ }^{a}$ Standard error $\left\{=1 / k_{\mathrm{D}}\left[\left(\Delta k_{\mathrm{H}}\right)^{2}+\left(k_{\mathrm{H}} / k_{\mathrm{D}}\right)^{2} \times\left(\Delta k_{\mathrm{D}}\right)^{2}\right]^{1 / 2}\right\}$.

more electron-withdrawing Y, noted as horizontal arrow of $\rightarrow$ in Table 4 . In contrast, the variation trends of the $k_{\mathrm{H}} / k_{\mathrm{D}}$ values with $\mathrm{X}$ for $\mathbf{8}$ are opposite to those for 10: the $k_{\mathrm{H}} / k_{\mathrm{D}}$ values become larger with a more electron-withdrawing $\mathrm{X}$ for $\mathbf{8}(\downarrow)$, whereas those become larger with a more electrondonating $X$ for $\mathbf{1 0}(\uparrow)$, noted as vertical arrows in Table 4 . At a glance, the variation trends of the $k_{\mathrm{H}} / k_{\mathrm{D}}$ values with $\mathrm{X}$ and/ or $\mathrm{Y}$ could be one of the strong tools to clarify the reaction mechanism: (i) 8, 9, 11 and 12, via a $\mathrm{S}_{\mathrm{N}} 2$ mechanism, show the variation trends of $\downarrow \rightarrow$; (ii) while 10, via a stepwise mechanism with a rate-limiting bond cleavage, shows $\uparrow \leftarrow$. However, the variation trends of the $k_{\mathrm{H}} / k_{\mathrm{D}}$ values with $\mathrm{X}$ and/ or Y cannot be the supporting evidence to substantiate the mechanism based on: (i) the anilinolysis of Y-aryl phenyl chlrophosphates, via a $\mathrm{S}_{\mathrm{N}} 2$ mechanism $\left(\rho_{\mathrm{XY}(\mathrm{H})}=-1.31\right)$, showing $\uparrow \leftarrow$; ${ }^{6 \mathrm{a}}$ (ii) Y-aryl ethyl chlorophosphates, via a $\mathrm{S}_{\mathrm{N}} 2$ mechanism $\left(\rho_{\mathrm{XY}(\mathrm{H})}=-0.60\right)$, showing $\downarrow \rightarrow$; ; (iii) Y-aryl 4chlorophenyl chlrophosphates, via a $\mathrm{S}_{\mathrm{N}} 2$ mechanism $\left(\rho_{\mathrm{XY}(\mathrm{H})}\right.$ $=-0.31$ ), showing $\uparrow \leftarrow^{6 \mathrm{~b}}$ (iv) $O$-aryl methyl phosphonochloridothioates, via a $\mathrm{S}_{\mathrm{N}} 2$ and stepwise mechanism with a rate-limiting bond cleavage $\left(\rho_{\mathrm{XY}(\mathrm{H})}=-0.95\right.$ and 0.77 with strongly and weakly basic anilines, respectively), showing $\uparrow \rightarrow ;^{9 \mathrm{a}}$ (v) Y-aryl phenyl isothiocyanophsphates, via a stepwise mechanism with a rate-limiting bond cleavage and $\mathrm{S}_{\mathrm{N}} 2$ $\left(\rho_{\mathrm{XY}(\mathrm{H})}=1.41\right.$ and -0.18 with the strongly and weakly basic anilines, respectively), showing $\uparrow \rightarrow ;^{9 \mathrm{~b}}$ (vi) Y-aryl ethyl isothiocyanophsphates, via a $\mathrm{S}_{\mathrm{N}} 2$ and stepwise mechanism with a rate-limiting bond cleavage $\left(\rho_{\mathrm{XY}(\mathrm{H})}=-0.14\right.$ and 3.89 with the strongly and weakly basic anilines, respectively), show- ing $\uparrow \rightarrow{ }^{9 \mathrm{c}}$ The $\beta_{\mathrm{X}(\mathrm{H})}$ values of $\mathbf{1 - 1 2}$ are relatively large in the range of $0.8-1.5$, and this indicates that it could be sometimes dangerous to suggest the reaction mechanism based on the $\beta_{\mathrm{X}(\mathrm{H})}$ values.

When partial deprotonation of the aniline occurs in a ratelimiting step by hydrogen bonding (e.g. TSf in Scheme 2), the $k_{\mathrm{H}} / k_{\mathrm{D}}$ values are greater than unity, primary normal $\left(k_{\mathrm{H}} / k_{\mathrm{D}}\right.$ $>1.0) .{ }^{10}$ In contrast, the DKIEs can only be secondary inverse $\left(k_{\mathrm{H}} / k_{\mathrm{D}}<1.0\right)$ when an increase in the steric congestion occurs in the bond-making process (e.g. TSb in Scheme 2), because the $\mathrm{N}-\mathrm{H}(\mathrm{D})$ vibrational frequencies invariably increase upon going to the TS. ${ }^{11}$ In this respect, primary normal and secondary inverse DKIEs are rationalized by a frontside equatorial attack involving hydrogen bonded four-center-type TSf and backside apical attack involving in-line-type TSb, respectively. In the case of 10, the min value of $k_{\mathrm{H}} / k_{\mathrm{D}}=0.62$ with $\mathrm{X}=3-\mathrm{Cl}$ and $\mathrm{Y}=4-\mathrm{MeO}$ indicates severe steric congestion in the TS. Table R1 lists six substrates, showing $\left(k_{\mathrm{H}} / k_{\mathrm{D}}\right)_{\min }<0.62$, studied in this lab. ${ }^{12}$ As seen in Table R1, there are no consistent relationships

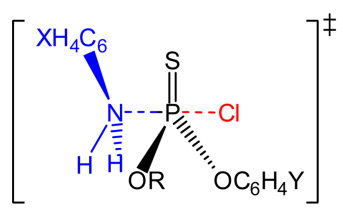

$\mathrm{TSb}$

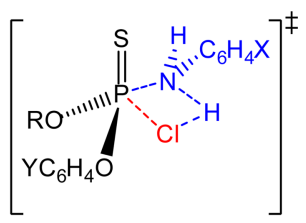

TSf
Scheme 2. Backside attack involving in-line-type TSb and frontside attack involving a hydrogen bonded, four-center-type TSf. 
Table 7. Second-Order Rate Constants $\left(k_{\mathrm{H}} / \mathrm{M}^{-1} \mathrm{~s}^{-1}\right)$ and Activation Parameters ${ }^{a}$ for the Reactions of $\mathbf{8}$ with $\mathrm{XC}_{6} \mathrm{H}_{4} \mathrm{NH} \mathrm{H}_{2}(\mathrm{X}=4-\mathrm{MeO}, \mathrm{H}, 4-\mathrm{Cl})$ in $\mathrm{MeCN}$

\begin{tabular}{|c|c|c|c|c|c|c|}
\hline \multirow{2}{*}{$\mathrm{Y}$} & \multirow{2}{*}{$\mathrm{X}$} & \multicolumn{3}{|c|}{$k_{\mathrm{H}} \times 10^{4} / \mathrm{M}^{-1} \mathrm{~s}^{-1}$} & \multirow{2}{*}{$\begin{array}{c}\Delta H^{\ddagger} / \\
\mathrm{kcal} \mathrm{mol}^{-1}\end{array}$} & \multirow{2}{*}{$\begin{array}{c}-\Delta S^{\ddagger} / \\
\mathrm{cal} \mathrm{mol}^{-1} \mathrm{~K}^{-1}\end{array}$} \\
\hline & & $45.0^{\circ} \mathrm{C}$ & $55.0^{\circ} \mathrm{C}$ & $65.0^{\circ} \mathrm{C}$ & & \\
\hline \multirow[t]{3}{*}{ 4-MeO } & $4-\mathrm{MeO}$ & $29.1 \pm 0.4$ & $42.5 \pm 0.2$ & $60.8 \pm 0.1$ & $7.2 \pm 0.1$ & $48 \pm 1$ \\
\hline & $\mathrm{H}$ & $3.52 \pm 0.01$ & $5.32 \pm 0.03$ & $8.20 \pm 0.01$ & $8.4 \pm 0.3$ & $48 \pm 1$ \\
\hline & $4-\mathrm{Cl}$ & $1.07 \pm 0.01$ & $1.74 \pm 0.02$ & $2.70 \pm 0.01$ & $9.3 \pm 0.2$ & $48 \pm 1$ \\
\hline \multirow[t]{3}{*}{$4-\mathrm{Me}$} & 4-MeO & $31.4 \pm 0.1$ & $49.0 \pm 0.1$ & $72.5 \pm 0.8$ & $8.3 \pm 0.1$ & $44 \pm 1$ \\
\hline & $\mathrm{H}$ & $4.00 \pm 0.02$ & $6.45 \pm 0.04$ & $10.7 \pm 0.1$ & $9.8 \pm 0.4$ & $43 \pm 1$ \\
\hline & $4-\mathrm{Cl}$ & $1.15 \pm 0.02$ & $1.97 \pm 0.01$ & $3.24 \pm 0.01$ & $10.4 \pm 0.1$ & $44 \pm 1$ \\
\hline \multirow[t]{3}{*}{$\mathrm{H}$} & 4-MeO & $39.0 \pm 0.1$ & $60.7 \pm 0.3$ & $94.4 \pm 0.2$ & $8.8 \pm 0.2$ & $42 \pm 1$ \\
\hline & $\mathrm{H}$ & $4.92 \pm 0.01$ & $7.85 \pm 0.01$ & $13.1 \pm 0.1$ & $9.8 \pm 0.5$ & $43 \pm 1$ \\
\hline & $4-\mathrm{Cl}$ & $1.43 \pm 0.01$ & $2.37 \pm 0.02$ & $3.88 \pm 0.01$ & $10.0 \pm 0.1$ & $45 \pm 1$ \\
\hline \multirow[t]{3}{*}{ 3-MeO } & 4-MeO & $52.5 \pm 0.4$ & $80.8 \pm 0.3$ & $123 \pm 1$ & $8.5 \pm 0.1$ & $43 \pm 1$ \\
\hline & $\mathrm{H}$ & $5.41 \pm 0.01$ & $8.49 \pm 0.01$ & $12.9 \pm 0.1$ & $8.6 \pm 0.1$ & $46 \pm 1$ \\
\hline & $4-\mathrm{Cl}$ & $1.77 \pm 0.01$ & $2.89 \pm 0.01$ & $4.35 \pm 0.03$ & $9.0 \pm 0.3$ & $48 \pm 1$ \\
\hline \multirow[t]{3}{*}{$4-\mathrm{Cl}$} & 4-MeO & $67.3 \pm 0.5$ & $105 \pm 1$ & $155 \pm 1$ & $8.2 \pm 0.3$ & $43 \pm 1$ \\
\hline & $\mathrm{H}$ & $7.68 \pm 0.02$ & $12.1 \pm 0.1$ & $19.9 \pm 0.3$ & $9.5 \pm 0.4$ & $43 \pm 1$ \\
\hline & $4-\mathrm{Cl}$ & $2.16 \pm 0.01$ & $3.79 \pm 0.01$ & $5.98 \pm 0.01$ & $10.3 \pm 0.5$ & $43 \pm 1$ \\
\hline
\end{tabular}

${ }^{a}$ Calculated by Eyring equation.

Table 8. Second-Order Rate Constants $\left(k_{\mathrm{H}} / \mathrm{M}^{-1} \mathrm{~s}^{-1}\right)$ and Activation Parameters ${ }^{a}$ for the Reactions of $\mathbf{1 0}$ with $\mathrm{C}_{6} \mathrm{H}_{5} \mathrm{NH}_{2}$ in $\mathrm{MeCN}$

\begin{tabular}{|c|c|c|c|c|c|}
\hline \multirow{2}{*}{ Y } & \multicolumn{3}{|c|}{$k_{\mathrm{H}} \times 10^{4} / \mathrm{M}^{-1} \mathrm{~s}^{-1}$} & \multirow{2}{*}{$\begin{array}{c}\Delta H^{\ddagger} / \\
\mathrm{kcal} \mathrm{mol}^{-1}\end{array}$} & \multirow{2}{*}{$\begin{array}{c}-\Delta S^{\ddagger} / \\
\mathrm{cal} \mathrm{mol}^{-1} \mathrm{~K}^{-1}\end{array}$} \\
\hline & $45.0^{\circ} \mathrm{C}$ & $55.0^{\circ} \mathrm{C}$ & $65.0^{\circ} \mathrm{C}$ & & \\
\hline $4-\mathrm{MeO}$ & $1.16 \pm 0.01$ & $1.55 \pm 0.01$ & $2.08 \pm 0.01$ & $5.6 \pm 0.2$ & $59 \pm 1$ \\
\hline $4-\mathrm{Me}$ & $1.31 \pm 0.01$ & $1.80 \pm 0.01$ & $2.40 \pm 0.01$ & $5.8 \pm 0.1$ & $58 \pm 1$ \\
\hline $\mathrm{H}$ & $1.53 \pm 0.01$ & $2.04 \pm 0.01$ & $2.79 \pm 0.01$ & $5.8 \pm 0.3$ & $58 \pm 1$ \\
\hline 3-MeO & $1.89 \pm 0.01$ & $2.63 \pm 0.01$ & $3.62 \pm 0.02$ & $6.3 \pm 0.1$ & $56 \pm 1$ \\
\hline $4-\mathrm{Cl}$ & $2.93 \pm 0.01$ & $4.09 \pm 0.01$ & $5.66 \pm 0.02$ & $6.4 \pm 0.1$ & $55 \pm 1$ \\
\hline
\end{tabular}

${ }^{a}$ Calculated by Eyring equation.

between: $\left(k_{\mathrm{H}} / k_{\mathrm{D}}\right)_{\min }$ and (i) $\mathrm{X}$; (ii) Y; (iii) anilinolysis mechanism as mentioned earlier.

Tables 7 and 8 list the activation parameters, enthalpies and entropies of activation, for the anilinolyses of $\mathbf{8}$ and $\mathbf{1 0}$, respectively. ${ }^{13}$ The enthalpies of activation are relatively low $\left(5-11 \mathrm{kcal} \mathrm{mol}^{-1}\right)$ and the entropies of activation are relatively large negative values $\left(-39\right.$ to $-59 \mathrm{cal} \mathrm{mol}^{-1} \mathrm{~K}^{-1}$ ) for the anilinolyses of 1-11 as seen in Table R2. ${ }^{14}$ The relatively low activation enthalpy and large negative activation entropy are typical for the aminolyses of the $\mathrm{P}=\mathrm{S}$ (and $\mathrm{P}=\mathrm{S}$ ) systems.

\section{Experimental Section}

Materials. Substrates of $\mathbf{8}$ and $\mathbf{1 0}$ were prepared as reported earlier. $^{15}$

Kinetic Procedure. The second-order rate constants and selectivity parameters were obtained as previously described. ${ }^{1}$ Initial concentrations were as follows; [substrate] $=5 \times 10^{-3}$ $\mathrm{M}$ and $[\mathrm{X}$-Aniline $]=(0.10-0.30) \mathrm{M}$ for both substrates.

Product Analysis. Phenyl methyl and 3-methoxyphenyl propyl chlorothiophosphate were reacted with excess aniline for more than 15 half-lives at $55.0^{\circ} \mathrm{C}$ in $\mathrm{MeCN}$. Acetonitrile was evaporated under reduced pressure. The product mix- ture was treated with ether by a work-up process with dilute $\mathrm{HCl}$ and dried over anhydrous $\mathrm{MgSO}_{4}$. The product was isolated through column chromatography (25-30\% ethyl acetate $/ n$-hexane) and then dried under reduced pressure. The analytical and spectroscopic data of the product gave the following results (supporting information):

$\left(\mathrm{C}_{6} \mathrm{H}_{5} \mathrm{O}\right)\left(\mathrm{CH}_{3} \mathrm{O}\right) \mathbf{P}(=\mathrm{S}) \mathbf{N H C}_{6} \mathbf{H}_{5}$. Brown gummy solid; ${ }^{1} \mathrm{H}-\mathrm{NMR}\left(400 \mathrm{MHz}, \mathrm{MeCN}-d_{3}\right) \delta 3.79-3.83(\mathrm{~d}, 3 \mathrm{H}), 6.67$ (d, br, $1 \mathrm{H}, J=8.8 \mathrm{~Hz}), 6.79-6.90(\mathrm{~d}, 1 \mathrm{H}), 7.02-7.09(\mathrm{t}, 1 \mathrm{H})$, 7.15-7.25 (m, 4H) 7.26-7.45 (m, 4H); ${ }^{13} \mathrm{C}-\mathrm{NMR}(100 \mathrm{MHz}$, $\left.\mathrm{MeCN}-d_{3}\right) \delta 54.26,115.97,118.17,119.56,121.89,123.4$, $126.2,130.19,130.9 ;{ }^{31} \mathrm{P}-\mathrm{NMR}$ (162 MHz, MeCN-d $\left.d_{3}\right)$ $\delta 74.36(\mathrm{P}=\mathrm{S}, 1 \mathrm{P}, \mathrm{d}, J=13.9 \mathrm{~Hz})$; GC-MS (EI, $m / z) 279$ $\left(\mathrm{M}^{+}\right)$.

$\left(3-\mathrm{CH}_{3} \mathrm{O}-\mathrm{C}_{6} \mathrm{H}_{4} \mathrm{O}\right)\left(\mathrm{C}_{3} \mathrm{H}_{7} \mathrm{O}\right) \mathbf{P}(=\mathrm{S}) \mathrm{NHC}_{6} \mathrm{H}_{5}$. Brown liquid; ${ }^{1} \mathrm{H}-\mathrm{NMR}\left(400 \mathrm{MHz}, \mathrm{CDCl}_{3}\right.$ and TMS) $\delta 1.19-1.26(\mathrm{~m}, 3 \mathrm{H})$, 1.74-1.76 (q, 2H), 3.71 (s, 3H), 4.04-4.24 (m, 2H), 5.56 (br. $\mathrm{d}, J=3.8 \mathrm{~Hz}, 1 \mathrm{H}), 6.70-6.77(\mathrm{~m}, 2 \mathrm{H}), 7.02(\mathrm{t}, 4 \mathrm{H}), 7.08(\mathrm{~d}$, $4 \mathrm{H}), 7.18(\mathrm{t}, 1 \mathrm{H}), 7.27-7.29(\mathrm{~m}, 2 \mathrm{H}) ;{ }^{13} \mathrm{C}-\mathrm{NMR}(100 \mathrm{MHz}$, $\mathrm{CDCl}_{3}$ and TMS) $\delta 10.2,23.3,55.3,69.4,107.3,111.3$, $113.5,118.0,122.5,129.4,129.8,139.2,151.4,160.4 ;{ }^{31} \mathrm{P}-$ NMR (162 MHz, $\mathrm{CDCl}_{3}$ and TMS) $\delta 66.9$ (1P, P=S); GCMS (EI, $m / z) 337\left(\mathrm{M}^{+}\right)$. 
Acknowledgments. This work was supported by Inha University Research Grant.

\section{References and Notes}

1. (a) Dey, N. K.; Hoque, M. E. U.; Kim, C. K.; Lee, B. S.; Lee, H. W. J. Phys. Org. Chem. 2008, 21, 544. (b) Barai, H. R.; Hoque, M. E. U.; Lee, H. W. Bull. Korean Chem. Soc. 2013, 34, 3811. (c) Hoque, M. E. U.; Lee, H. W. Bull. Korean Chem. Soc. 2011, 32, 4403. (d) Hoque, M. E. U.; Lee, H. W. Bull. Korean Chem. Soc. 2012, 33, 843. (e) Hoque, M. E. U.; Dey, N. K.; Kim, C. K.; Lee, B. S.; Lee, H. W. Org. Biomol. Chem. 2007, 5, 3944. (f) Hoque, M. E. U.; Dey, S.; Guha, A. K.; Kim, C. K.; Lee, B. S.; Lee, H. W. J. Org. Chem. 2007, 72, 5493.

2. (a) Taft, R. W. Steric Effect in Organic Chemistry; Newman, M. S., Ed.; Wiley: New York, 1956; Chapter 3. (b) Exner, O. Correlation Analysis in Chemistry: Recent Advances; Chapman, N. B., Shorter, J., Eds.; Plenum Press: New York, 1978; p 439.

3. ' $\Sigma E_{\mathrm{S}}=E_{\mathrm{S}}\left(\mathrm{R}_{1}\right)+E_{\mathrm{S}}\left(\mathrm{R}_{2}\right)$ ' is employed instead of ' $\Sigma E_{\mathrm{S}}=E_{\mathrm{S}}\left(\mathrm{R}_{1} \mathrm{O}\right)+$ $E_{\mathrm{S}}\left(\mathrm{R}_{2} \mathrm{O}\right)$ ' because the data of $E_{\mathrm{S}}\left(\mathrm{R}_{\mathrm{i}} \mathrm{O}\right)$ is not available $\left[E_{\mathrm{S}}(\mathrm{R})=\right.$ $0(\mathrm{Me}) ;-0.07(\mathrm{Et}) ;-0.36(\mathrm{Pr}) ;-0.39(\mathrm{Bu}) ;-0.47(i-\mathrm{Pr}) ;-2.48(\mathrm{Ph})]$.

4. (a) Lee, I. Chem. Soc. Rev. 1990, 19, 317. (b) Lee, I. Adv. Phys. Org. Chem. 1992, 27, 57. (c) Lee, I.; Lee, H. W. Collect. Czech. Chem. Commun. 1999, 64, 1529. (d) Lee, I.; Lee, H. W. Bull. Korean Chem. Soc. 2001, 22, 732.

5. The substrate of $\mathbf{1 2}$ is excluded to consider the steric effects of the two ligands on the rate. The anilinolysis rate of $\mathbf{1 2}($ with $\mathrm{Y}=\mathrm{H})$ is faster than that of $\mathbf{1 1}$ (with $\mathrm{Y}=\mathrm{H}$ ) due to an electron-withdrawing ability of the 4-chloro substituent, although the steric effects of the two ligands of $\mathbf{1 2}$ would be slightly greater than those of $\mathbf{1 1}$ in the TS.

6. (a) Guha, A. K.; Lee, H. W.; Lee, I. J. Chem. Soc., Perkin Trans. 2 1999, 765. (b) Lee, H. W.; Guha, A. K.; Lee, I. Int. J. Chem. Kinet. 2002, 34, 632. (c) Hoque, M. E. U.; Lee, H. W. Bull. Korean Chem. Soc. 2011, 32, 3245. (d) Hoque, M. E. U.; Lee, H. W. Bull. Korean Chem. Soc. 2012, 33, 663. (e) Hoque, M. E. U.; Lee, H. W. Bull. Korean Chem. Soc. 2012, 33, 1879.

7. The correlation coefficients of the sensitivity coefficients $(\delta)$ of $\mathrm{r}=$ 0.948 with $a$ group and $\mathrm{r}=0.803$ with $b$ group indicate relatively poor linear correlation between the steric effects and rate. However, the tendency of the linearity between them could be acceptable i.e., 'not quantitatively but qualitatively' in Figure 2. The problem is that there is no other way to rationalize the steric effects of the two ligands on the rate except Taft eq.

8. As mentioned earlier, the authors suggest that the degrees of both bond formation and cleavage with $\mathbf{1 0}$ are greater than those with $\mathbf{8}$ in the TS based on the magnitudes of the selectivity parameters, $\beta_{\mathrm{X}(\mathrm{H}),} \rho_{\mathrm{X}(\mathrm{H})}$ and $\rho_{\mathrm{Y}(\mathrm{H})}$. The CICs have the advantage of the indication of the degree of tightness of the TS structure based on the interaction between the two substituents.

9. (a) Hoque, M. E. U.; Guha, A. K.; Kim, C. K.; Lee, B. S.; Lee, H. W. Org. Biomol. Chem. 2009, 7, 2919. (c) Barai, H. R.; Lee, H. W.
Beilstein J. Org. Chem. 2013, 9, 615. (e) Barai, H. R.; Adhikary, K. K.; Lee, H. W. Bull. Korean Chem. Soc. 2013, 34, 1829.

10. (a) Lee, I.; Koh, H. J.; Lee, B. S.; Lee, H. W. J. Chem. Soc., Chem. Commun. 1990, 335. (b) Lee, I. Chem. Soc. Rev. 1995, 24, 223. (c) Marlier, J. F. Acc. Chem. Res. 2001, 34, 283. (d) Westaway, K. C. Adv. Phys. Org. Chem. 2006, 41, 217. (e) Villano, S. M.; Kato, S.; Bierbaum, V. M. J. Am. Chem. Soc. 2006, 128, 736. (f) Gronert, S.; Fagin, A. E.; Wong, L. J. Am. Chem. Soc. 2007, 129, 5330.

11. (a) Yamata, H.; Ando, T.; Nagase, S.; Hanamura, M.; Morokuma, K. J. Org. Chem. 1984, 49, 631. (b) Zhao, X. G.; Tucker, S. C.; Truhlar, D. G. J. Am. Chem. Soc. 1991, 113, 826. (c) Poirier, R. A.; Wang, Y.; Westaway, K. C. J. Am. Chem. Soc. 1994, 116, 2526.

12. Table R1. $\left(k_{\mathrm{H}} / k_{\mathrm{D}}\right)_{\min }$ of Six Substrates where $\left(k_{\mathrm{H}} / k_{\mathrm{D}}\right)_{\min }<0.62$

\begin{tabular}{ccccc}
\hline substrate & $\left(k_{\mathrm{H}} / k_{\mathrm{D}}\right)_{\min }$ & $\mathrm{X}$ & $\mathrm{Y}$ & ref. \\
\hline$(\mathrm{Me})\left(\mathrm{YC}_{6} \mathrm{H}_{4} \mathrm{O}\right) \mathrm{P}(=\mathrm{S}) \mathrm{Cl}$ & 0.37 & $4-\mathrm{Cl}$ & $4-\mathrm{CN}$ & $9 \mathrm{a}$ \\
$\left(\mathrm{Me}_{2} \mathrm{~N}\right)\left(\mathrm{YC}_{6} \mathrm{H}_{4} \mathrm{O}\right) \mathrm{P}(=\mathrm{O}) \mathrm{Cl}$ & 0.42 & $3-\mathrm{Cl}$ & $4-\mathrm{MeO}$ & $\mathrm{a}$ \\
$\left.(\mathrm{Ph})\left(\mathrm{YC}_{6} \mathrm{H}_{4} \mathrm{O}\right) \mathrm{P}=\mathrm{S}\right) \mathrm{Cl}$ & 0.44 & $4-\mathrm{MeO}$ & $4-\mathrm{MeO}$ & $\mathrm{b}$ \\
$(\mathrm{PhO})(\mathrm{PhNH}) \mathrm{P}(=\mathrm{O}) \mathrm{Cl}$ & 0.52 & $3-\mathrm{Cl}$ & - & $\mathrm{c}$ \\
$\left.\left[\mathrm{C}_{2} \mathrm{H}_{2} \mathrm{NOC}(=\mathrm{O})\right]_{2} \mathrm{P}=\mathrm{O}\right) \mathrm{Cl}$ & 0.61 & $3-\mathrm{Cl}$ & - & $\mathrm{d}$ \\
$\left.(\mathrm{PhO})\left(\mathrm{YC}_{6} \mathrm{H}_{4} \mathrm{O}\right) \mathrm{P}=\mathrm{O}\right) \mathrm{Cl}$ & 0.61 & $4-\mathrm{Cl}$ & $4-\mathrm{Cl}$ & $6 \mathrm{a}$ \\
\hline
\end{tabular}

(a) Barai, H. R.; Lee, H. W. Bull. Korean Chem. Soc. 2014, 35, 753. (b) Hoque, M. E. U.; Lee, H. W. Bull. Korean Chem. Soc. 2011, 32, 3505. (c) Hoque, M. E. U.; Lee, H. W. Bull. Korean Chem. Soc. 2012, 33, 3437. (d) Barai, H. R.; Lee, H. W. Bull. Korean Chem. Soc. 2013, 34, 3218.

13. The activation parameters were obtained extensively to find the consistent trends with $\mathrm{X}$ and/or $\mathrm{Y}$, however, there is no correlation between the activation parameters and substituents. Moreover, the activation enthalpy-entropy compensation phenomena do not exist.

14. Table R2. Activation Parameters for the Reactions of 1-11 with $\mathrm{C}_{6} \mathrm{H}_{5} \mathrm{NH}_{2}$ in $\mathrm{MeCN}$

\begin{tabular}{cccc}
\hline substrate & $\begin{array}{c}\Delta H^{\sharp} / \\
\mathrm{kcal} \mathrm{mol}^{-1}\end{array}$ & $\begin{array}{c}-\Delta S^{\ddagger} / \\
\mathrm{cal} \mathrm{mol}^{-1} \mathrm{~K}^{-1}\end{array}$ & ref. \\
\hline 1: $(\mathrm{MeO})_{2} \mathrm{P}(=\mathrm{S}) \mathrm{Cl}$ & 8.0 & 49 & $1 \mathrm{a}$ \\
2: $(\mathrm{MeO})(\mathrm{EtO}) \mathrm{P}=\mathrm{S}) \mathrm{Cl}$ & 11.2 & 39 & $1 \mathrm{~b}$ \\
3: $(\mathrm{EtO})_{2} \mathrm{P}(=\mathrm{S}) \mathrm{Cl}$ & 6.0 & 55 & $1 \mathrm{a}$ \\
4: $(\mathrm{EtO})(\mathrm{PrO}) \mathrm{P}=\mathrm{S}) \mathrm{Cl}$ & 7.3 & 52 & $1 \mathrm{~b}$ \\
$\mathbf{5 :}(\mathrm{PrO})_{2} \mathrm{P}(=\mathrm{S}) \mathrm{Cl}$ & 7.3 & 53 & $1 \mathrm{c}$ \\
6: $(\mathrm{BuO})_{2} \mathrm{P}(=\mathrm{S}) \mathrm{Cl}$ & 7.4 & 52 & $1 \mathrm{~d}$ \\
7: $(i-\mathrm{PrO})_{2} \mathrm{P}(=\mathrm{S}) \mathrm{Cl}$ & 9.4 & 47 & $1 \mathrm{~b}$ \\
8: $(\mathrm{MeO})(\mathrm{PhO}) \mathrm{P}=\mathrm{S}) \mathrm{Cl}$ & 9.8 & 43 & present work \\
9: $(\mathrm{EtO})(\mathrm{PhO}) \mathrm{P}=\mathrm{S}) \mathrm{Cl}$ & 5.4 & 59 & $1 \mathrm{e}$ \\
10: $(\mathrm{PrO})(\mathrm{PhO}) \mathrm{P}=\mathrm{S}) \mathrm{Cl}$ & 5.8 & 58 & present work \\
11: $(\mathrm{PhO})_{2} \mathrm{P}(=\mathrm{S}) \mathrm{Cl}$ & 7.7 & 54 & $1 \mathrm{f}$ \\
\hline
\end{tabular}

15. Barai, H. R.; Lee, H. W. Bull. Korean Chem. Soc. 2014, 35, 483. 